\title{
A MORTIFICAÇÃO DO CORPO EM É ISTO UM HOMEM? DE PRIMO LEVI
}

\author{
José Carlos Felix \\ Universidade do Estado da Bahia \\ Jacobina, BA, BR \\ Juliana Cristina Salvadori ${ }^{* *}$ \\ Universidade do Estado da Bahia \\ Jacobina, BA, BR
}

\begin{abstract}
Resumo
Dentre os incontáveis testemunhos e narrativas que se propuseram denunciar, narrar e dar sentido à experiência produzida pela Shoah, o livro É isto um homem?, do escritor italiano Primo Levi, prefigura como um dos relatos mais contundentes acerca dos horrores e monstruosidades vividas nos campos de concentração nazistas durante a Segunda Guerra Mundial. O presente artigo propõe uma discussão acerca das formas de violência e mortificação do corpo apontadas no relato de Levi, as quais revelam um processo de reificação da vida, cujas consequências mais diretas afetam tanto a relação do indivíduo com seu próprio corpo quanto com o do outrem. Para tanto, partiremos do testemunho do autor acerca do processo de reificação e degradação humana, bem como das reflexões sobre a relação entre esclarecimento e barbárie pensadas por Horkheimer e Adorno e dos conceitos de soberania e biopolitização do estado chamada de "vida nua" de Agamben.
\end{abstract}

Palavras-chave: Shoah; mortificação; corpo; biopolitização; Primo Levi.

\section{THE MORTIFICATION OF THE BODY IN IF THIS IS A MAN? BY PRIMO LEVI}

\begin{abstract}
Amongst countless testimonies and narratives engendered by Shoah, the book, If this is a man, by the Italian writer, Primo Levi, stands as one of the most remarkable accounts on the horrors and monstrosities experienced in the Nazi concentration camps during World War II. This essay aims at discussing the issues of violence and the body mortification found in Levi's account, which, in turn, reveal a process of reification of life whose consequences affect profoundly the relationship between the individual and his/her body as well as the body of others. The discussion is grounded on the author's narration concerning the process of human reification and degradation as well as on Horkheimer and Adorno's considerations on the relationship between enlightenment and barbarism alongside with the concepts of sovereignty and the state of biopoliticization, known as "naked life", thought by Agamben.
\end{abstract}

Key words: Shoah; mortification; body; biopoliticization; Primo Levi.

\footnotetext{
José Carlos Felix é Doutor em Teoria e História Literária (2013) pelo IEL/UNICAMP e Professor Adjunto da Universidade do Estado da Bahia, Campus IV. É também professor permanente do Programa de Pós-Graduação em Crítica Cultural do Campus II, onde coordena grupo de pesquisa Pós-teoria. Email: jcfelixjuranda@yahoo.com.br

** Juliana Cristina Salvadori é Doutora em Literaturas de Língua Portuguesa pelo Programa de Pós-Graduação em Letras da Pontifícia Universidade Católica (PUC Minas). É Professora Assistente da Universidade do Estado da Bahia (UNEB) e coordenadora do grupo de Pesquisa Desleituras em série: da tradução como transcriação, adaptação, refração, diáspora. Email: ju.salvadori@gmail.com
} 
Este trabalho propõe interpretar a narrativa sobre a Shoah em É Isto um Homem? (Se Questo é um Uomo, 1947), do escritor italiano Primo Levi, partindo da questão inevitável que o autor se/nos faz, por extensão, logo de saída, no título do livro': É isto um homem?. O dêitico "isto", uma das possíveis traduções de questo, aponta a reificação do indivíduo e sua redução à corporeidade violada. Ou seja, não esse, este ou aquele, mas isto, pronome neutro, acentuando o afastamento do humano, do ser homem que o título-questão evoca - afastamento este que, assumimos, a elaboração da narrativa busca problematizar. Já de saída, a ambivalência contida na questão pesa, pois "isso" - o que fora outrora "quem", na experiência de degradação do campo nazista, converte-se em "isto" - abarca paradoxalmente tanto a vítima quanto o seu algoz. Ademais, é preciso atentar para as escolhas de tradução para língua portuguesa, que ora contemplam a conjunção "se", presente no título original, e ora sofrem apagamento, uma vez que a indagação "se isto é um homem?" pressupõe não apenas a questão posta, mas a construção de um argumento nos moldes da lógica - se isto, logo aquilo - que não se completou/completa. Em outras palavras, temos uma aporia acerca da impossibilidade, contida no gesto da narração, de se racionalizar plenamente sobre a experiência do horror vivido.

Dito isso, se, num primeiro plano, a narrativa de Levi emerge como um gesto necessário de elaboração da experiência do horror, por outro, a forma fragmentada e a atenção a detalhes aparentemente banais convertem-se no pesadelo de estar em uma sala cercada de pessoas que não o escutam, que não o querem escutar, impedindo assim que o sonho recorrente de purgar o sofrimento pela narração não se concretize. Levi sempre enfatizou o fato de que o seu relato fora recebido, a princípio, com certa indiferença e menoscabo pelos leitores - indiferença e menoscabo que o próprio narrador prevê enquanto (re)pensa e narra sua experiência. Todavia, é justamente esse querer ser escutado que se converte no mote da narrativa de É Isto um Homem?. Em uma sociedade que pensa e aceita o testemunho como o manifesto/atestação do visto - testemunho de tribunal -, em sua narrativa, Levi salienta o desejo de reelaborar o horror a partir do testemunho como encarado pela psicanálise - testemunho oral que se quer e precisa ser ouvido, acolhido pelo outro, saindo do testemunho telescópico/visual para o auricular, des-centrando a narrativa do "fato", da atestação, para a testemunha - sua experiência. Isso é ilustrado por Selligman-Silva em seu artigo Testemunho e a política da memória: o tempo depois das catástrofes (2005), no qual se propõe, justamente, abordar as diferentes noções de testemunho: testemunho como atestação da verdade, testis, inaugurado na protocena da Oresteia de Ésquilo, visual e falocêntrico; testemunho como sobrevivência da/à narrativa, modelo auricular, do superstes/sobrevivente. $\mathrm{O}$ testemunho centrado na própria experiência.

Afinal, é como se apenas por meio da escrita, e de uma escrita que circula o real, esse real traumático, que de fato é sempre intocável pela representação, o autor pudesse acessar sua experiência como testis e superstes, ${ }^{2}$ isto é, tanto na condição de testemunha quanto na condição de sobrevivente (não pensamos que essas duas dimensões possam ser distinguidas, nesse caso). Essa escolha pelo fragmento e pela mediação do corpo da literatura para se narrar instaura uma recusa: a narrativa/relato/testemunho de Levi se nega como forma narrativa totalizadora. Ou seja, como narrativa dotada de uma função teleológica na busca de um sentido tout court dessa experiência e narrativa dialógica - que se assume construção literária em diálogo com outros textos/experiências, exercendo em si mesma a dimensão de escuta que busca. É justamente dessa forma que o corpo do texto e, por extensão, o corpo do sobrevivente procuram se reconstruir a partir de outra lógica que não a do ver/conhecer/saber/testemunhar.

O corpo da escrita de Levi, portanto, converte-se em um corpo/escrita que busca não tanto esse impossível real, mas sim o que pode ser narrado a partir de outros corpos narrativos, outras vozes encontrados na tradição literária ocidental, a saber: o Inferno de Dante - e sua dimensão de expiação do pecado; Ecce Homo, de Nietzsche, e sua reflexão (a)moral sobre o homem; O Processo e A metamorfose de Kafka e o absurdo, o não sentido da experiência. Todavia, essa narrativa não se recusa a pensar o processo de degradação humana erigido pelo projeto nazista de extermínio de seres entendidos como inu- ou sub-humanos, em suas 
bordas: isto é, pensar as demais e nem sempre explicitadas razões de como essa degradação consubstanciou-se, sobretudo, na instância corpórea. Com efeito, a narrativa de $\hat{E}$ isto um homem? não se limita ao mero relato de uma sucessão de episódios, mas apresenta um genuíno esforço em compreender as nuances que entrecortam esse evento inaudito, particularmente no que tange à ambivalente relação do homem para com o seu corpo - real e simbólico.

Nesse sentido, o esboço de uma possível resposta à questão posta de saída, já no título, exige cautela, e esta cautela parte do pensar sobre a re-apresentação dessa experiência - trauma e enigma, como a chama Agamben (2010) - e a problemática da (im)possibilidade de representação da experiência da Shoah: a barbárie e a aniquilação do homem, baseada na ambivalente relação deste com seu corpo. Corpo este que tem no campo de concentração - dito campo de trabalho, limiar que se assemelha ao do inferno dantesco, com inscrição inicial em sua chegada: "ARBEIT MACHT FREI", isto é, “o trabalho liberta” (LEVI, 1988, p. 20) - a exacerbação de uma lógica política que, segundo Agamben (2010), vai partir do que ele denomina de vida nua - essa vida desenvestida de sua sacralidade, pura zoé, que a rotina de trabalho no campo de concentração busca regular soberanamente. Mas antes de avançarmos nessa discussão é preciso enfatizar a ligação do corpo aprisionado, do corpo no campo de trabalho, no sentido de reiterar a tensão contida na relação corpo e trabalho.

Na Dialética do Esclarecimento (coincidentemente publicada em 1947), Horkheimer e Adorno examinam como a passagem do homem para o esclarecimento, por meio do domínio da natureza, converteu-se no paradoxo que o subjugou a um estado de controle e violência. Com efeito, no bojo das questões que fundam a contraditória relação de amor/ódio pelo corpo, emergem também reflexões da imbricada relação entre mito, homem e natureza - sintomática expressão do cruzamento e da disjunção entre cultura e natureza. Nesse ponto, tanto Horkheimer e Adorno quanto Levi chancelam a tese de que a modernidade assinalou o corpo como uma instância fundamental do discurso filosófico. ${ }^{3}$ Com efeito, várias questões circunscritas à violência/violação no/do corpo, contidas na obra de Levi, aproximam-se das reflexões assinaladas pelos filósofos frankfurtianos e continuam a ecoar também no debate sobre o contemporâneo de Agamben (2010). Ou seja, é a partir da figura do homo sacer, na dimensão da vida/ corpo matável, mas não sacrificável, e da biopolitização que as estratégias de controle do estado ocorrem. Do mesmo modo, faz-se necessário também pensar o ato de aniquilamento desta vida/corpo, visto que este ato impossibilita a expiação da pena, do crime por parte de quem o comete, uma forma de expiação simbólica que legalmente não se afigura crime ou transgressão do ordenamento político-jurídico a morte dessa vida. A vida indigna de ser vivida, vida e corpo que estão ao mesmo tempo dentro e fora do ordenamento, da norma e que põem em xeque e em voga a questão da soberania como classicamente formulada por Schmitt: "soberano é aquele que decide sobre o estado de exceção" (apud AGAMBEN, 2010, p. 18).

Desse modo, reiteradamente durante a narrativa e já no primeiro capítulo de É Isto um Homem?, Levi destaca que a chegada ao campo de concentração foi marcada pela emblemática frase pendurada acima do portal de entrada, à guisa de boas-vindas e aviso: "ARBEIT MACHT FREI" - "o trabalho liberta" (LEVI, 1988, p. 20). Ao longo da narrativa, Levi assinala que, mais do que uma morte rápida - reservada principalmente às mulheres, crianças e velhos - os não úteis -, nos campos de concentração, a via mais efetiva encontrada pelos algozes para executar o projeto de degradação humana deu-se justamente pelo trabalho. Lógica bárbara do aproveitamento máximo do corpo já degradado, porque não mais visto como humano, o campo de concentração, de trabalho, produzia, de fato, o inumano, a não humanidade. As primeiras impressões de Levi atestam a tese da mortificação do corpo pelo trabalho expressa nos relatos de que:

Emergiram, em compensação, na luz dos holofotes, dois grupos de sujeitos estranhos. Caminhavam em linhas de três, com um andar esquisito, atrapalhado, a cabeça baixa, os braços rígidos. (...) Entreolhávamo-nos sem dizer uma palavra. Tudo era incompreensível e louco, mas entendêramos algo: aquela era a metamorfose que nos esperava. Amanhã, nós também estaríamos assim. (LEVI, 1988, p. 19) 
E, mais adiante:

Já não existe vontade; cada pulsão torna-se passo, contração reflexa dos músculos destruídos. Os alemães conseguiram isso. Dez mil prisioneiros, uma única máquina cinzenta; estão programados, não pensam, não querem. Marcham. (LEVI, 1988, p. 50)

Assim, após relatar o meticuloso processo de "iniciação" ao qual os recém-chegados ao campo eram submetidos, Levi constata que, aqueles que não eram enviados diretamente aos fornos e câmaras de gás passavam por um ritual a partir do qual os corpos eram submetidos a um processo de desinvestimento de sua individualidade - assinalada, por exemplo, em suas roupas, nos cortes de cabelo, na subtração dos pertences e minudências (fotos, chaves, papéis, sapatos) -, transformando-os em produtos fabricados em série. Ademais, ele evidencia que no campo de concentração não havia espelhos, tampouco a necessidade deles, pois a imagem de cada um estava agora na face do outro, "refletida em cem rostos pálidos, em cem bonecos sórdidos e miseráveis" (LEVI, 1988, p. 24). Era a monstruosa constatação de que todos os detentos se encontravam em meio a um meticuloso processo que findaria por transformar a todos nos mesmos fantasmas que eles haviam avistado na noite da chegada àquele lugar.

Ainda, segundo o testemunho de Levi, nesse cenário perverso, a ordem do trabalho opera por meio de duas funções basilares: a tortura e a reificação. $\mathrm{O}$ trabalho, observa ele, é para todos e, com exceção dos doentes, ${ }^{4}$ distribuído entre os prisioneiros de acordo com as qualificações oriundas de suas vidas pregressas. Contudo, apesar de "cada qual estar destinado a certa oficina ou setor da fábrica, e depender de maneira mais direta de mestres civis", todos estão subordinados diretamente aos “alemães e poloneses" (LEVI, 1988, p. 33). As horas de trabalho são extenuantes, pois "um domingo em cada dois é dia normal de trabalho e, nos domingos de folga, em vez de trabalhar na fábrica trabalha-se, em geral, na manutenção do Campo" (LEVI, 1988, p. 33). Assim, a vida resume-se em uma eterna sucessão de dias nos quais se levanta, se trabalha, enquanto se espera pela morte. $\mathrm{O}$ que havia diante dos algozes era apenas um corpo - corpo inferior - totalmente destituído de subjetividade ou singularidade, que precisava ser aniquilado via ascese, neste caso, a do trabalho. Essa lenta, mas inexorável aniquilação diária e processual impacta pelo seu horror. Contudo, estranhamente, nota-se uma recusa na narrativa de Levi em se ater a detalhes dos episódios de tortura: as câmaras de gás não parecem ter exercido/exercer maior apelo sobre o leitor comum.

Chama a atenção que a lógica da violência infringida ao corpo por meio do trabalho, denunciada por Levi ao longo de todo o livro, é também tema de um ensaio intitulado Interesse pelo corpo, encontrado ao final da Dialética do Esclarecimento (ADORNO; HORKHEIMER, 2006, p. 190-94). Nele, os autores asseveram que a situação de dominação característica do capitalismo acentuou a já clássica dicotomia hierárquica entre corpo e alma, fundada em uma sociedade de classes pautada estritamente na divisão entre o trabalho manual — no sentido de uma atividade laboriosa ${ }^{5}$ e indigna - e a atividade intelectual, ou do lazer - uma grei restrita a poucos seres superiores. Segundo os autores, essa cisão histórica perpassou diversas formações sociais e discursivas da tradição ocidental e foi acompanhada por um processo de detratação e "mutilação que afeta sobretudo a relação com o corpo" (ADORNO; HORKHEIMER, 2006, p. 190). Ironicamente, a mesma conjuntura que ideou a atividade intelectual como uma ascese forjadora de uma superioridade de poucos, desprezando e humilhando o corpo e o trabalho como instâncias inferiores, tomou como reféns também os detratores do corpo, já que "quanto menos os senhores podiam dispensar o trabalho dos outros, mais desprezível ele se tornava a seus olhos"' (ADORNO; HORKHEIMER, 2006, p. 190).

A expressão mais notória para essa conjuração traduziu-se no estigma que assolou principalmente aqueles indivíduos cujo corpo ficou, historicamente, associado ao trabalho, a saber: o escravo, o servo e, na modernidade, o trabalhador. Contudo, foi nos campos de concentração que o trabalho como atividade punitiva e ascética desvela sua mais horrenda faceta, extraindo do homem não apenas sua força orgânica, mas reduzindo-o a um estado inaudito, como Levi elucida na seguinte passagem: 
Já apareceram, no peito de meus pés, as torpes chagas que nunca irão sarar. Empurro vagões, trabalho com a pá, desfaleço na chuva, tremo no vento; mesmo meu corpo já não é meu; meu ventre está inchado, meus membros ressequidos, meu rosto túmido de manhã e chupado à noite; alguns de nós têm a pele amarelada, outros cinzenta; quando não nos vemos durante três ou quatro dias, custamos a reconhecernos. (LEVI, 1988, p. 35)

Foi justamente essa configuração do trabalho como elemento de tortura que permeou todas as práticas não apenas nos campos de concentração particular, mas em todas as colônias penais, a exemplo daquelas descritas por Kafka (1997). A ordem do sistema moderno de produção compreende o corpo como uma instância descartável quando esse já não se encontra mais em condições de realização plena das tarefas de labor - como a condição infeliz de Gregor Samsa na Metamorfose de Kafka.

Outro aspecto na relação de detração e tortura infligida ao corpo descrita por Levi refere-se ao modo pelo qual tanto a organização quanto o modus operandi do campo operavam sob padrões de produção industrial. Ou seja, a matéria-prima a ser transformada e manufaturada não era outra que não o próprio homem, visto como mera engrenagem na maquinaria maior da ordem de produção em larga escala. Esse processo de inserção dos detentos na rotina de labor do campo segue um modelo de operação extremamente complexo e elaborado, seguido de várias fases, como explica Levi.

O tratamento do homem e do corpo como coisa já é demonstrado na maneira como os detentos eram transportados para os campos. Esse processo de inserção dos detentos na rotina de labor do campo segue um modelo de operação extremamente complexo e elaborado, dividido em várias fases, como explica Levi: todos chegavam de trem, apinhados em grandes vagões de carga, como matéria-bruta a ser eventualmente manufaturada. Nesses vagões, "trancados por fora, e, dentro, homens, mulheres e crianças eram socados sem piedade, como mercadoria barata, a caminho do nada, morro abaixo, para o fundo" (LEVI, 1988, p. 15). Levi rememora o diálogo no qual o sargento indaga ao cabo a quantidade de indivíduos transportados, ao que o cabo prontamente responde que "as peças eram seiscentas e cinquenta, e que tudo estava em ordem" (LEVI, 1988, p.14).

Não obstante, é a rotina de trabalhos forçados dos campos que confirmará essa lógica funesta de gradual extirpação da humanidade. Ela se inicia propriamente com o apagamento da identidade e da subjetividade de cada indivíduo através da troca dos nomes por números de série. Tal procedimento ocorre pela seleção e catalogação daqueles que se mostram mais aptos para as atividades pesadas de trabalho e consiste em tatuar um "número de série", o qual servirá para identificar o prisioneiro doravante. Em seu testemunho, Levi espanta-se, apieda-se e sente repulsa à completa conformação a essa desumanização, personificada por um dos prisioneiros que visivelmente se esforça em emular os protocolos de seus algozes. Ao relatar o caso de um amigo que assombrara Levi por sua completa adaptação à nova alcunha, o escritor destaca a maneira como o reconhecimento entre eles ocorria, visto que a longa série de números era reduzida, no tratamento cotidiano, a apenas os três algarismos finais, "como se todos tivessem compreendido que só os homens têm direito a um nome, e que Null Achtzehn já não é um homem" (LEVI, 1988, p. 41). Em seu triste relato, Levi especula que era muito provável que o amigo, em sua ânsia por uma adaptação que lhe assegurasse a sobrevivência, já esquecera o próprio nome e, quando falava e olhava para ele, tinha a impressão de que ele estava "interiormente oco, nada mais que um invólucro, como certos despojos de insetos que encontramos na beira de pântanos, ligados por um fio às pedras e balançados pelo vento" (LEVI, 1988, p. 41).

Contudo, o mais espantoso está no fato de que os relatos descritos por Levi sugerem que os pormenores do sistema de organização do trabalho no campo de concentração e do cotidiano de seus detentos trata-se de um ordenamento já existente no mundo da norma, da não exceção, ou como ele próprio assevera, "da vida em liberdade". O autor ainda adensa sua crítica ao acrescentar que "só bem mais tarde, pouco a pouco, alguns de nós aprenderam algo da macabra ciência dos números de Auschwitz, na qual se resumem as etapas da destruição do judaísmo europeu" (LEVI, 1988, p. 
26). Mais adiante, Levi sugere que foi justamente a ampliação do domínio e do controle de tudo que cerca o homem ao próprio corpo que resultou na experiência dos campos de concentração.

Na reflexão de Horkheimer e Adorno, esse ímpeto de dominação absoluta pela razão, apanágio central do processo civilizatório, foi marcado pela tomada de tudo aquilo que se encontra em sua totalidade, a exemplo do próprio corpo, a fim de separá-lo em várias partes, examinando-o como um objeto tout court. Ao examinar as razões da barbárie do homem sobre o outrem, engendrado no projeto de extermínio de seres humanos, Horkheimer e Adorno atentam também para a maneira pela qual a divisão do trabalho, estabelecida na configuração capitalista, baseia-se em uma longa tradição religiosa dualista entre corpo e espírito, corroborando para uma cisão da humanidade em dois grupos distintos: superiores e inferiores - os que pensam e os que trabalham. Segundo os autores, essa disjunção firmou a noção de que "o corpo explorado devia representar para os inferiores o que é o mau e o espírito, para os que tinham o ócio necessário, devia representar o sumo bem" (ADORNO; HORKHEIMER, 2006, p. 191). A ascese aqui posta seria alcançada por um processo de sublimação que, quando fracassado, resultaria naquilo que os autores denominam amor-ódio pelo corpo.

Por outro lado, a apologia ao cultivo do espírito e detração do corpo, feita pelos superiores, extirpa também neles o que é vivo, pois, através da corporificação, também advém toda e qualquer forma de criação cultural, uma pujante força que transforma o que é vivo, Leib, em coisa morta, Körper e vice-versa. Nas palavras dos autores: "não podemos nos livrar do corpo e nós o louvamos quando não podemos golpeá-lo" (ADORNO; HORKHEIMER, p. 193). Levi pontua toda sua narrativa com os mais diversos exemplos de como, desde a chegada ao campo de concentração, o corpo deixa de ser algo vivo, Leib, sendo tratado como matéria morta, Körper. Seu tratamento como coisa reificada perpassa todas as instâncias do campo, não se restringindo apenas aos locais de trabalho e, como relata, uma simples consulta no ambulatório, confirma a tese da dimensão irrisória na qual o corpo se reduziu:
O enfermeiro aponta as minhas costelas ao outro, como se eu fosse um cadáver na sala de anatomia; mostra as pálpebras, as faces inchadas, o pescoço fino; inclina-se faz pressão com o dedo em minha canela, indicando a profunda cavidade que o dedo deixa na pálida carne, como se eu fosse de cera. (LEVI, 1988, p. 48)

Do mesmo modo, outro intrigante aspecto no horizonte da narrativa de Levi concerne o gradual processo de adaptação que emerge na vida cotidiana do campo e que, de maneira mais nefasta e perversa, assegura a sobrevivência de alguns poucos. A exemplo do episódio do colega, acima descrito, destaca-se, em particular, a passagem em que o autor esquadrinha o desenvolvimento das inúmeras microrrelações de poder que entrecortam o tecido das "relações sociais" entre os detentos (LEVI, 1988, p. 88). Em um momento de profunda reflexão, Levi pondera acerca de como as noções de humanidade e civilização têm suas fronteiras obliteradas diante da infame luta pela sobrevivência na massacrante rotina do campo - há de se pensar, por exemplo, no episódio da sopa extra: diz o autor, "quando saciados podíamos então pensar em nossas esposas e mães e ser infelizes à maneira dos homens normais".

Para ele, o campo de concentração foi "uma notável experiência biológica e social", pois basta apenas fechar com cercas de arame farpado e submeter milhares de indivíduos de diferentes idades, condições sociais, origens, língua e cultura a uma mesma rotina exaustiva de trabalhos forçados e todo o aparato que constitui a organicidade da vida social humana irá desaparecer (LEVI, 1988, p. 88). O resultado desse "experimento", conclui Levi, será a constatação "de que o homem é essencialmente brutal, egoísta e estulto, como parece demonstrar o seu comportamento ao ruir toda a estrutura social", já que, diante do sofrimento físico, muitos hábitos, e, sobretudo, "muitos dos instintos sociais são reduzidos ao silêncio" (LEVI, 1988, p.88). Assim, é com esse espírito que Levi enumera, dentro da rotina do campo de concentração, a pletora de micro-universos, onde cada indivíduo encontra-se sozinho e onde, acima de tudo, parece valer mais do que nunca a máxima "a quem tem, será dado; de quem não tem, será tirado" (LEVI, 1988, p. 90). 
As microrrelações de poder, acima deslindadas, podem ser ainda entendidas como uma forma de reordenamento advindo do estado de exceção, descrito por Agamben, retomando a definição clássica de soberano - o que decide sobre o estado de exceção, sobre a norma: o campo de concentração, estado de exceção máximo, replica a lógica da exceção político-jurídica e multiplica os soberanos. Em outras palavras, o campo de concentração torna-se locus de pequenos e múltiplos soberanos: o kappo, o commander, cada soldado, os criminosos comuns (alemães e poloneses) - todos esses acabam sendo, em algum momento, soberanos sobre essa vida que é matável, mas não sacrificável, uma vida indigna, pois

[b]asta oferecer a alguns indivíduos em estado de escravidão uma situação privilegiada, certo conforto e uma boa probabilidade de sobrevivência, exigindo em troca a traição da natural solidariedade com os companheiros, e haverá por certo quem aceite. Ele será subtraído à lei comum e se tornará intangível; será, então, tanto mais odioso e odiado quanto maior for o poder a ele concedido. (LEVI, 1988, p. 92)

Não obstante, se por um lado, a condenação do corpo "detratado" baseou-se no entendimento desse como refúgio irrestrito de uma pulsão destruidora e antagônica ao espírito, expressão suprema do bem, por outro, uma outra versão do corpo "exaltado" sempre prefigurou ao longo da história como a matéria prima essencial para as grandes produções culturais e artísticas europeias - o belo clássico, proporcional e harmônico. O próprio delírio nazista de uma raça pura, da exaltação à estética greco-romana com uma representação da instância corpórea delineada por contornos nítidos e definidos, assinala o paroxismo de uma exaltação paradoxal ao corpo "perfeito" e, ao mesmo tempo, uma detração pelos corpos que não se subscrevessem a esse padrão. Com efeito, no campo de concentração, o corpo dos subjugados não poderá atingir esse ideal de perfeição e ascese - esse corpo que é tido como imundo -, uma vez que a questão da higiene funciona como outra estratégia no processo de mortificação desse corpo. Ou seja, paradoxalmente se exalta a higiene e se nega aos detentos as condições mínimas para exercê-la. Levi elucida essa obsessiva preocupação e cuidado com a higiene pessoal e sua conspícua impossibilidade naquelas condições precárias:

Durante semanas, considerei estas exortações à higiene como simples traços de humor teutônico (...). Mais tarde, porém, compreendi que seus ignotos autores não estavam (talvez inconscientemente) longe de importantes verdades. Neste lugar, lavar-se cada dia na água turva da pia imunda, bem pouco adianta quanto ao anseio e à saúde; é extremamente importante, porém, como sintoma de resídua vitalidade, e essencial com meio de sobrevivência moral. Tenho que confessar: bastou uma semana de cativeiro para sumir meu hábito de limpeza. (LEVI, 1988, p. 38)

Logo, o ato de higiene - o lavar-se, mesmo com água suja - torna-se importante apenas pelo seu valor simbólico: o gesto emula uma rotina normativa dentro da rotina de exceção do campo.

De modo análogo, as considerações de Horkheimer e Adorno insistem no caráter dialético e ambivalente da relação com o corpo, que, na medida em que fora "escarnecido e repelido como algo inferior e escravizado", também foi amado, desejado: no já citado paradoxo amor-ódio. Todavia, sua reificação, seu tratamento como coisa, como objeto sem vida, proibido, alienado, consolidou sua exaltação. Assim, observa-se que as questões do corpo na modernidade refletem a mesma lógica do produtor dos bens de consumo com as mercadorias que produz; caracterizado no fetichismo da mercadoria que, dada a diminuta participação do trabalhador no processo de produção do bem, oblitera as relações sociais, de exploração do trabalho alheio pelo capital, que de fato a produzem. Lógica semelhante aplica-se ao corpo, obediente à mesma ordem produtiva que manufatura toda matéria bruta em bem de consumo: o corpo reificado. Estabelece-se aqui uma inversão da relação hierárquica entre indivíduo e objeto, em que o primeiro é deslocado para o segundo polo, configurando-se em um quadro no qual o indivíduo aliena-se de si próprio e busca no consumo de uma pletora de produtos e marcas a restauração de uma 
imagem de si outrora perdida. ${ }^{7}$ É precisamente esse não reconhecimento de si e do outrem que Levi testemunha em sua experiência no cativeiro, adensada ainda mais por uma necessidade premente de adaptação que lhe assegure a vida. No que tange ao ímpeto de adaptação o autor ressalta:

\begin{abstract}
A capacidade humana de cavar-se uma toca, de criar uma casa, de erguer ao redor de si uma tênue barreira defensiva, ainda que em circunstâncias aparentemente desesperadas, é espantosa e mereceria um estudo profundo. Trata-se de um preciso trabalho de adaptação, parte passivo e inconsciente, parte ativo: cravar um prego no beliche para pendurar os sapatos, à noite; ajustar tácitos acordos de não agressão com os vizinhos; intuir e aceitar os hábitos e leis peculiares do Kommando e do Bloco. (LEVI, 1988, p. 56)
\end{abstract}

Como o trecho acima assinala, a destruição do indivíduo aparece indissociavelmente atrelada à problemática da renúncia, do sacrifício, a qual é severamente examinada por Levi ao logo de todo o livro. Acerca do sacrifício, Horkheimer e Adorno asseveram que "a história de civilização é a história da introversão do sacrifício" (ADORNO; HORKHEIMER, 2006, p. 54) e, em uma bela e densa passagem sobre o tema, partem da asserção de que na conversão do sacrifício em subjetivação encontra-se também o aspecto da astúcia constitutivo do sacrifício. Isto é, a "inverdade da astúcia, a fraude presente no sacrifício" configura-se na mutilação do herói, cujo semblante traz a fisionomia marcada pelos golpes que ele infligiu a si próprio a fim de assegurar sua autoconservação. Há nessa passagem a imbricação de dois elementos importantes que elucidam precisamente o argumento central de Horkheimer e Adorno, a saber: a assimilação da coerção da natureza por uma falsa mímesis. De modo semelhante às observações sobre o processo de adaptação ao sofrimento e violência, essa falsa mímesis, no entanto, ao mesmo tempo em que permite a autopreservação dos prisioneiros nos campos de concentração, também os impede de perceber o antagonismo entre seu ego e a natureza.

Todavia, o fato de, durante séculos, a humanidade não ter atentado para o entrelaçamento entre ambos, ou ainda, ter concebido, sob a chancela do discurso filosófico, mito e esclarecimento como categorias antagônicas, explica-se justamente pelo esforço de seu esquecimento, engendrado no processo civilizatório. Horkheimer e Adorno salientam que, "no modo de produção burguês, a indelével herança mimética de toda a práxis é abandonada ao esquecimento", visto que a obsessão dos homens pela civilização subtraiu-lhes qualquer percepção de seus traços miméticos (ADORNO; HORKHEIMER, 2006, p. 150). Logo, a reflexão imbricada no bojo dessa tese evidencia os efeitos ardilosos da mímesis sobre a instância corpórea, pois, para os autores, na sociedade contemporânea, tais traços miméticos são apenas percebidos na forma de certos gestos e comportamentos "como tocar, aconchegar-se, aplacar, induzir" - que se tornaram tabus e já foram, há muito tempo, reprimidos pela civilização. Já os relatos de Levi sobre o campo de concentração, por sua vez, mostram que a falsa mímesis de que falam os frankfurtianos fez emergir a face mais sombria e sórdida do indivíduo.

Em suma, ao longo de toda sua narrativa, Levi toca em um ponto nevrálgico ao esquadrinhar o percurso de vários de seus companheiros que encontram nessa forma de adaptação a chave para se manter vivos durante a estada em Auschwitz. Segundo ele, muitos prisioneiros que não foram favorecidos pela sorte tiveram que lutar com as próprias forças e empregar os artifícios mais ardilosos para travar a batalha de cada dia. Eles precisaram nadar contra a correnteza, contra o cansaço, contra a fome, o frio e a inércia; porém, a batalha maior, foi a de "resistir aos inimigos e não ter penas dos rivais" (LEVI, 1988, p. 93). A denúncia de Levi retoma a reflexão de Horkheimer e Adorno acerca da falsa mímesis, de como a desvirtuação do comportamento mimético no processo de adaptação serviu puramente fins ideológicos. No caso dessa falsa projeção, porém, um indivíduo aviltado projeta no mundo exterior apenas o vazio que se tornou sua interioridade, pois

[j]á não existe vontade; cada pulsão torna-se passo, contração reflexa dos músculos destruídos. Os alemães conseguiram isso. Dez mil prisioneiros, uma única máquina cinzenta; estão programados, não pensam, não querem. Marcham. (p. 50) 
E assim, erige-se um indivíduo adequadamente adaptado ao comando do Führer e o resultado disso é alteração profunda nas bases da percepção no sentido de que o antissemita passa a literalmente "ver" os objetos do mundo exterior a partir daquilo que o comando determina, já que o indivíduo-objeto é visto com hostilidade, como um animal cujo sacrifício não acarretaria nenhum prejuízo para a sociedade. Mais alarmante ainda é a constatação de Levi acerca daqueles que sobreviveram ao holocausto e, como ele, puderam eventualmente relatar os horrores e a barbárie lá experienciada. Para muitos, a sobrevivência foi assegurada ao custo do desprendimento de qualquer valor moral, algo que arrefece ainda mais a linha tênue que separa e distingue o carrasco de sua vítima.

\section{Considerações finais}

À guisa de encerrarmos a presente discussão acerca do entrelaçamento das questões atinentes à violência corpórea e barbárie nos relatos de Levi em É Isto um Homem?, alguns pontos merecem ser salientados a título de fechamento. Destacamos que uma leitura atenta dessa obra evidencia que as vicissitudes imbricadas na questão do corpo configuram-se em uma relação substitutiva marcada pela ambivalência e que, no cenário inaudito dos campos de concentração, a detração e a violência infligidas ao corpo deram-se tanto pelo trabalho como forma de extirpação da força orgânica quanto pela reificação que conferiu ao corpo, outrora vivo, Leib, um status em coisa morta, Körper; a exemplo das reflexões de Horkheimer e Adorno sobre o tema.

Além disso, a manifestação dos aspectos reprimidos do corpo, pensada primeiramente por Freud e posteriormente elaborada por Horkheimer e Adorno como um meio de expressão de uma falsa identificação, uma falsa mímesis expressa na forma constitutiva dos elementos do anti-semitismo, permite uma compreensão mais ampla da denúncia de Levi acerca da metamorfose dos convictos nos campos, cuja sobrevivência foi, em muitos casos, assegurada pela aproximação entre o algoz e a vítima. Adorno, em outro texto, Teoria da Semicultura (1993), retorna a essa reflexão e parte da observação de que a marcada assimetria entre "o poder e a impotência social" nega tanto aos impotentes quanto aos superiores os pressupostos reais para a emancipação efetiva (ADORNO, 1993, p. 26). Nesse argumento transparece o imperativo que expõe a disparidade entre poder e impotência social, a qual afeta a todos indistintivamente, convertendo-se em danos formativos tanto aos detentores de poder quanto aos deste desprovidos. Ou seja, uma sugestão de que o modelo de opressão e violência dos campos de concentração encontra-se plasmado nas práticas cotidianas, a exemplo da indústria cultural que subordina todos à lógica do capital, ao poder e aos modelos estereotipados de percepção e comportamento que aquele fornece.

Reconhecer e refletir acerca desse descompasso permite, sobretudo, um reconhecimento mais lúcido não apenas da ação coercitiva da natureza no homem, dentro e fora do espaço territorial dos campos (sejam eles nazistas ou congêneres), conforme Levi, Horkheimer, Adorno e Agamben procuram explicitar ao longo de suas obras, assim como os desdobramentos oriundos dessa fusão. Isto é, o conjunto de aporias como a autorreflexão contida na relação do amor e ódio pelo corpo, a excitação dos sentidos, e o próprio conceito de impotência social refletido de forma direta na impotência de um corpo orgânico, imperfeito e incompleto, diametralmente distinto do corpo sem marcas de imperfeição e ascéptico celebrado e cultuado pela indústria cultural, cuja expressão mais sombria e nefasta culminou no projeto de eugenia perpetrado pela Shoah aqui discutida.

Contudo, a leitura e a reflexão das questões pensadas por Horkheimer, Adorno e Agamben e testemunhadas por Levi parecem cada vez mais reverberar em nossos ouvidos, quando observamos outras formas de violência contra o corpo, travestidas em outras expressões de uma eugenia auto-infligida ao corpo e que abarcam as mais diversas esferas da vida contemporânea. O exame dessas questões e de seus possíveis desdobramentos, no entanto, evidencia a impossibilidade de esgotamento da questão e sugere uma extensa pauta para a continuidade dessa discussão. 


\section{Notas}

1. No título em original, em italiano, a pergunta é formulada da seguinte forma: Se Questo é um Uomo? (título optado para a edição de língua Portuguesa, Se Isto é um Homem?).

2. Cf. Seligman-Silva, "Testemunho e a política da memória: o tempo depois das catástrofes" (2005, p. 80/81).

3. Na segunda metade do século XX, o debate sobre o corpo desdobrou-se em outras vertentes no contexto das ideias contemporâneas, embora ainda fortemente mobilizadas por um impulso crítico semelhante às reflexões dos filósofos frankfurtianos, e em sintonia com as novas realidades do mundo da tecnologia. As últimas décadas têm testemunhado o complexo e sempre polêmico debate sobre corpo naquilo que se notabilizou como biopoder e biopolítica. Nessa esfera, as obras de Foucault, em particular nos volumes da História da Sexualidade, podem ser tomadas como instâncias discursivas desse debate.

4. Levi destaca ainda que ser reconhecido como um doente não era uma tarefa das mais fácies, e somente aqueles com uma ampla bagagem e experiência é que se saiam bem-sucedidos na empreitada (LEVI, 1988, p. 33).

5. Vale ressaltar que a própria etimologia da palavra trabalho, uma variação do verbete latino tripalium, denomina um instrumento de tortura, um indicativo de que as marcas etimológicas revelam a idéia do trabalho como punição e atividade repulsiva em oposição ao "cultivo" do espírito e do intelecto.

6. Em seu instigante livro Mrs. Woolf and the Servants: An Intimate History of Domestic Life in Bloomsbury (Sra. Woolf e seus Empregados: Uma intima história da vida doméstica em Bloomsbury, 2008) a autora inglesa Alison Light investiga a conflituosa relação que a célebre escritora e feminista inglesa Virginia Woolf manteve com seus empregados em sua mansão em Bloomsbury, bairro nobre de Londres e residência de vários influentes intelectuais ingleses da época, notabilizados como o grupo de Bloomsbury. Nesse livro, Light descreve os conflitos e dilemas de Woolf que, ao mesmo tempo em que se estabelecera como uma figura proeminente na vanguarda das lutas pelos direitos e emancipação das mulheres e subalternos, encontravase extremamente dependente de seus serviçais (Sophie e Maud, cozinheira e arrumadeira, que viviam no porão da mansão). Segundo os relatos extraídos de seus diários, Woolf relutava com o fato de se perceber incapaz de realizar simples tarefas domésticas, como preparar a própria comida, e essa evidente contradição com seu papel de intelectual "esclarecida" refletia-se no tratamento hostil e mesquinho que ela mantinha com aqueles que a serviam.
7. Vale ressaltar que o debate contemporâneo sobre o corpo na sociedade de consumo, sobretudo nos autores que abordam questões concernentes à cultura do consumo na sociedade pós-moderna, sedimentou ainda mais o lugar de destaque do corpo no discurso social. Em A Ética Romântica e o Espírito do Consumismo Moderno, por exemplo, Campbell (2001) parte das análises de Max Weber (2004) para traçar a genealogia do consumo, baseado na tese de que os protestantes weberianos encontraram na relação com as mercadorias uma forma de fruição tolerável, resultado de um processo que visava sublimar os prazeres sensuais. As origens do consumismo moderno, argumenta Campbell, pautaram-se em uma forma de ascese forjadora da identidade burguesa na relação com o consumo de objetos (CAMPBELL, 2001). Entretanto, as transformações do sistema econômico, ocorridas ao longo do século $\mathrm{XX}$, em especial as geradas pela indústria cultural e pelo capitalismo tardio, adensaram ainda mais a importância da relação entre os bens de consumo e o corpo na constituição de subjetividades, tornando-as, por sua vez, cada vez mais diametralmente invertidas.

\section{Referências}

ADORNO, Theodor Ludwig Wiesengrund. Theory of Pseudo-Culture. A Quarterly Journal of Critical Thought. Number: 95, 1993.

ADORNO, Theodor Ludwig Wiesengrund; HORKHEIMER, Max Dialética do Esclarecimento. Trad. Guido Antônio de Almeida. Rio de Janeiro: Jorge Zahar, 2006.

AGAMBEN, Giorgio. Homo Sacer: o Poder Soberano e a Vida Nua. Belo Horizonte: Editora UFMG, 2010.

CAMPBELL, Colin. A Ética Protestante e Espírito do Consumismo Moderno. Trad. Mauro Gama. Rio de Janeiro: Rocco, 2001.

DANTE, Alighieri. Divina Comédia. Tradução de João Tretino Ziller. Campinas: Atelie, 2011.

FOUCAULT, Michel. História da Sexualidade. A vontade de saber. Trad. Maria T. C. Albuquerque e J. A. Guilhon Albuquerque. São Paulo: Graal, 2005.

FREUD, Sigmund. Obras Completas. Tradução de Paulo Cesar de Souza. São Paulo: Companhia das Letras, 2010.

HORKHEIMER, Max. Eclipse da Razão. Trad. Sebastião Uchoa Leite. São Paulo: Centauro Editora, 2007.

KAFKA, Franz. A Metamorfose. Rio de Janeiro: Civilização Brasileira, 1997.

O processo. Tradução de Modesto Carone. São Paulo: Companhia das Letras, 2005. 
KANT, Immanuel. Resposta à Pergunta: Que é Esclarecimento? $<$ Aufklärung $>$. Textos Seletos. Trad. Floriano de Sousa Fernandes. Petrópolis: Vozes, 1985.

LEVI, Primo. É Isto um Homem?. Luigi Del Re. Rio de Janeiro: Rocco, 1988.

LIGHT, Alison. Mrs. Woolf and the Servants: An Intimate History of Domestic Life in Bloomsbury. London: Penguin, 2008.

NIETZSCHE, Friedrich. Ecce Homo. Tradução de Paulo Cesar de Souza. São Paulo: Companhia de Bolso, 2008.

SELIGMANN-SILVA, M. Testemunho e a política da memória: o tempo depois das catástrofes. Proj. História, São Paulo, (30), p. 71-98, jun. 2005.

Recebido em: 31/05/2015

Aceito em: 14/09/2015 
